\title{
Chemical Composition and Biological Activity of Allium cepa L. and Allium $\times$ cornutum (Clementi ex Visiani 1842) Methanolic Extracts
}

\author{
Željana Fredotović ${ }^{1}$, Matilda Šprung ${ }^{2}$, Barbara Soldo ${ }^{2}$, Ivica Ljubenkov ${ }^{2}$, Irena Budić-Leto ${ }^{3}$, \\ Tea Bilušić ${ }^{4}$, Vedrana Čikeš-Čulić ${ }^{5}$ and Jasna Puizina ${ }^{1, *}$ \\ 1 Department of Biology, Faculty of Science, University of Split, R. Boškovića 33, 21000 Split, Croatia; \\ zfredotov@pmfst.hr \\ 2 Department of Chemistry, Faculty of Science, University of Split, R. Boškovića 33, 21000 Split, Croatia; \\ msprung@pmfst.hr (M.Š.); barbara@pmfst.hr (B.S.); iljubenk@pmfst.hr (I.L.) \\ 3 Institute for Adriatic Crops and Karst Reclamation, Put Duilova 11, 21000 Split, Croatia; \\ irena.budic-leto@krs.hr \\ 4 Department for Food technology and Biotechnology, Faculty of Chemistry and Technology, \\ University of Split, R. Boškovića 35, 21000 Split, Croatia; tea@ktf-split.hr \\ 5 Department of Medical Chemistry and Biochemistry, School of Medicine, University of Split, Šoltanska 2, \\ 21000 Split, Croatia; vedrana.cikes.culic@mefst.hr \\ * Correspondence: puizina@pmfst.hr; Tel.: +385-21-619-260
}

Academic Editor: Gerold Jerz

Received: 12 January 2017; Accepted: 6 March 2017; Published: 11 March 2017

\begin{abstract}
Here, we report a comparative study of the phytochemical profile and the biological activity of two onion extracts, namely Allium cepa L. and Allium $\times$ cornutum (Clementi ex Visiani 1842), members of the family Amaryllidaceae. The identification of flavonoids and anthocyanins, and their individual quantities, was determined by high-performance liquid chromatography (HPLC). The potency of both extracts to scavenge free radicals was determined by the DPPH (2,2'-diphenyl-1-picrylhydrazyl) radical-scavenging activity and oxygen radical absorbance capacity (ORAC) methods. The DNA protective role was further tested by the single-cell gel electrophoresis (COMET) assay and by Fenton's reagent causing double-strand breaks on the closed circular high copy pUC19 plasmid isolated from Escherichia coli. In the presence of both extracts, a significant decrease in DNA damage was observed, which indicates a protective role of Allium cepa and Allium $\times$ cornutum on DNA strand breaks. Additionally, cytotoxicity was tested on glioblastoma and breast cancer cell lines. The results showed that both extracts had antiproliferative effects, but the most prominent decrease in cellular growth was observed in glioblastoma cells.
\end{abstract}

Keywords: onions; Allium $\times$ cornutum; Allium cepa; phenolic compounds; antioxidant activity; genotoxicity; antimutagenic activity; antiproliferative activity

\section{Introduction}

Oxidative stress is the disturbance between the production of reactive oxygen species (ROS) and antioxidant defenses. Overproduction of ROS can cause damage to important biomolecules, such as DNA, proteins, lipids, and carbohydrates, resulting in a variety of diseases [1]. For this reason, living cells have developed antioxidant systems to control free radicals and lipid peroxidation, and to maintain the oxidative-antioxidative balance [2]. Dietary antioxidants also play an important role in the suppression of oxidative stress, which may cause initiation and progression of various diseases, including cancer. Therefore, the consumption of dietary antioxidants is considered to be an effective tool in preventing diseases that may be caused by oxidative stresses [3]. The genus Allium covers more 
than 750 species distributed all over the northern hemisphere [4]. The members of this genus are known not only as flavored vegetables and spices, but also as medical plants that have been used in traditional medicines [5,6]. Among other Allium species, Allium cepa L. (the common onion) is one of the oldest plants cultivated worldwide [7]. Many epidemiological studies confirmed that dietary consumption of onions is associated with a reduced risk of developing many forms of cancer and cardiovascular and neurodegenerative diseases [8-10]. Their beneficial effect on health is attributed to high contents of biologically active phytomolecules, such as phenolic compounds, especially flavonoids, and several organosulfur compounds [11]. The most abundant flavonoids found in onions are quercetins, namely quercetin- $4^{\prime}$-monoglucoside and quercetin-3,4'-diglucoside, which account for more than $85 \%$ of the total flavonoid content $[12,13]$. In addition to flavonoids, onions, especially the red varieties, are a rich source of anthocyanins. The most frequently reported anthocyanins in red onions are cyanindin derivatives, although minor amounts of peonidin, petunidin, and delphidin derivatives have also been identified [14]. A. $\times$ cornutum (Clementi ex Visiani 1842) is a triploid hybrid onion $(2 n=3 x=24)$ originating from three parental species (A. cepa, A. pskemense B. Fedt., and A. roylei Stearn), traditionally cultivated in coastal Croatia under the name 'Ljutika' (shallot) [15]. Due to its tasty bulbs and leaves, this onion is widely used as a spice and its cultivation has spread to other parts of the world, such as Southeast Asia and Europe. To our knowledge, the chemical composition and biological activity of A. $\times$ cornutum have not been studied so far. This motivated us to identify and quantify major phenolic compounds present in the bulbs of $A . \times$ cornutum and $A$. cepa and to assess the biological activity (free radical scavenging potential, antimutagenic activity, antiproliferative activity on cancer cells, and antigenotoxic activity) of these widely used plants.

\section{Results and Discussion}

\subsection{HPLC Analysis of Flavonols and Anthocyanin and Total Phenolic Content of the Two Onion Species}

Two major and three minor fine peaks were successfully resolved by high-performance liquid chromatography (HPLC) UV-VIS analysis of flavonols in A. $\times$ cornutum and A. cepa methanolic extracts (Figure 1). The resulting chromatograms were qualitatively similar, which is in line with other reported studies [16-20]. Here, the two major peaks were identified as quercetin 3,4'-diglucoside (1) (retention time $\left(t_{\mathrm{R}}\right)$ for $A$. cepa $33.26 \mathrm{~min} ; t_{\mathrm{R}}$ for $A . \times$ cornutum $33.30 \mathrm{~min}$ ) and quercetin $4^{\prime}$-monoglucoside (2) ( $t_{\mathrm{R}}$ for $A$. сера $41.41 \mathrm{~min} ; t_{\mathrm{R}}$ for $A$. $\times$ cornutum $41.45 \mathrm{~min}$ ). The three minor peaks were identified as myricetin (3) ( $t_{\mathrm{R}}$ for $A$. cepa $43.34 \mathrm{~min} ; t_{\mathrm{R}}$ for $A$. $\times$ cornutum $43.37 \mathrm{~min}$ ), quercetin aglycone (4) $\left(t_{\mathrm{R}}\right.$ for A. сера $48.13 \mathrm{~min} ; t_{\mathrm{R}}$ for $A$. $\times$ cornutum $48.17 \mathrm{~min}$ ), and isorhamnetin (5) ( $t_{\mathrm{R}}$ for $A$. cepa $52.94 \mathrm{~min}$; $t_{\mathrm{R}}$ for A. $\times$ cornutum $52.97 \mathrm{~min})$. Two main quercetin conjugates, (1) and (2), together account for about $80 \%$ of the total flavonol content in both onions (Table 1).

Similar concentrations of the two quercetin conjugates were previously observed in other studies [16-19], confirming that the two are indeed predominant flavonols in onions. However, in this work, somewhat higher concentrations of (1) and (2) were observed in $A . \times$ cornutum, which agrees with the higher total phenolic content (TPC) $($ A. $\times$ cornutum TPC $6.63 \pm 0.31 \mathrm{mg}$ caffeic acid (CA)/g dry weight (DW); A. cepa TPC $6.24 \pm 0.23$ CA/g DW) accounted for in this onion species.

Our obtained TPC values show a good correlation to those reported by Santas et al. [21]. In their study, TPC values of the two methanolic extracts of Spanish onion varieties ranged from 5.15 to $6.33 \mathrm{mg}$ gallic acid equivalents (GAE)/g DW for white onions, and 2.48 to $2.58 \mathrm{mg}$ GAE/g DW for Calçot de Valls onions. However, it should be noted that TPC values could vary depending on the location of the cultivar and on the solvent used during the extraction process [1,21-24].

Furthermore, quantification of individual anthocyanins was carried out using HPLC (Table 1) where three anthocyanins in $A$. cepa and four in $A . \times$ cornutum were identified. Three anthocyanins, equal in both onions, were further identified as peonidin glucoside (6), petunidin glucoside (7), and malvidin glucoside (8). Interestingly, the fourth anthocyanin, delphidin glucoside (9), was found only in the $A$. $\times$ cornutum extract (Figure S2A,B). The only study reporting the presence of delphidin 
glucoside in Tropea red onions was reported by Gennaro et al. [14]. In addition to delphidin glucoside, they have also identified petunidin derivatives, and together these accounted for $\sim 30 \%$ of the total anthocyanins in the onion bulbs.
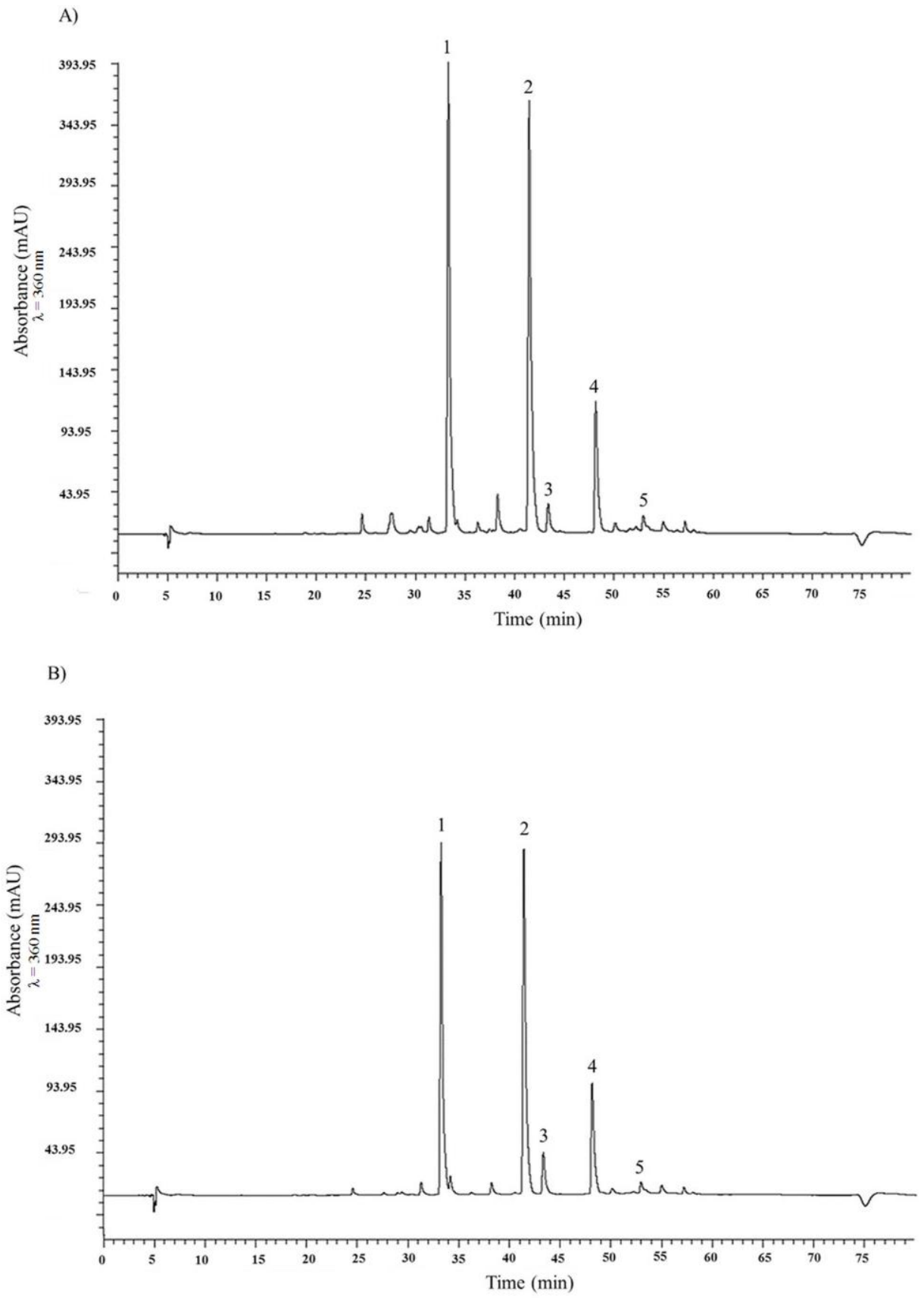

Figure 1. High-performance liquid chromatography (HPLC) chromatograms of $A . \times$ cornutum (A) and A. cepa (B) methanolic extracts at $360 \mathrm{~nm}$. Depicted are peaks: (1) quercetin 3,4'-diglucoside; (2) quercetin 4'-monoglucoside; (3) quercetin; (4) ishorhamnetin; and (5) kaempferol. 
Table 1. HPLC quantification of flavonols and anthocyanins in $A$. cepa and $A$. $\times$ cornutum extracts.

\begin{tabular}{lcc}
\hline & A. $\times$ cornutum $\left(t_{\mathbf{R}}, \mathbf{m i n}\right)$ & A. cepa $\left(t_{\mathbf{R}}, \mathbf{m i n}\right)$ \\
\hline Flavonols $^{\text {a }}$ & & \\
\hline Quercetin 3,4'-diglucoside (1) $^{\prime}$ & $240.01 \pm 0.39(33.30)$ & $171.34 \pm 0.13(33.26)$ \\
Quercetin 4'-monoglucoside (2) & $159.86 \pm 0.09(42.45)$ & $117.38 \pm 0.17(41.41)$ \\
Myricetin (3) & $6.22 \pm 0.09(43.37)$ & $8.02 \pm 0.02(43.34)$ \\
Quercetin aglycone (4) & $24.13 \pm 0.08(48.17)$ & $19.85 \pm 0.03(48.13)$ \\
Isorhamnetin (5) & $7.43 \pm 0.05(52.97)$ & $4.74 \pm 0.01(52.94)$ \\
\hline Anthocyanins ${ }^{\text {a }}$ & & \\
\hline Peonidin 3'-glucoside (6) & $0.54 \pm 0.00(11.35)$ & $0.19 \pm 0.00(12.11)$ \\
Petunidin 3'-glucoside acetate (7) & $0.52 \pm 0.00(21.72)$ & $0.13 \pm 0.01(22.58)$ \\
Delphinidin 3'-glucoside (9) & $0.15 \pm 0.00(31.37)$ & $\mathrm{Nd}$ \\
Malvidin 3'-glucoside (8) & $0.01 \pm 0.00(39.27)$ & $0.03 \pm 0.00(38.87)$ \\
\hline
\end{tabular}

${ }^{a}$ Concentrations in $\mathrm{mg} / 100 \mathrm{~g}$ of dry weight; $t_{\mathrm{R}}$, retention time.

\subsection{Antioxidant Activity}

In order to determine the antioxidant potential of our extracts, two tests were performed, 2,2'-diphenyl-1-picrylhydrazyl (DPPH) and the oxygen radical absorbance capacity (ORAC) assay. Both onions showed mutually similar DPPH and ORAC values at a concentration of $100 \mu \mathrm{g} / \mathrm{mL}$ (Table 2). However, slightly higher antioxidant activity was observed for $A . \times$ cornutum in the ORAC assay, which can be attributed to a slightly higher phenolic content. The high antioxidant scavenging activity of Allium species was reported in other studies where it was shown that this property depends on the existence of both phenolic and organosulfur compounds [24-29].

Table 2. Antioxidative potential of $A$. $\times$ cornutum and A. cepa methanolic extracts determined by DPPH and ORAC methods.

\begin{tabular}{ccc}
\hline Antioxidant Assay & A. $\times$ cornutum $(\mathbf{1 0 0} \mu \mathrm{g} / \mathrm{mL})$ & A. cepa $(\mathbf{1 0 0} \mu \mathrm{g} / \mathrm{mL})$ \\
\hline DPPH $(\%$ DPPH inhibition) & $60.50 \pm 3.84$ & $64.82 \pm 5.31$ \\
ORAC $(\mu \mathrm{mol} \mathrm{TE} / \mathrm{mL})$ & $19.38 \pm 2.21$ & $17.62 \pm 0.57$ \\
\hline
\end{tabular}

DPPH, 2,2'-diphenyl-1-picrylhydrazyl; ORAC, oxygen radical absorbance capacity.

\subsection{DNA Nicking Assay}

Taking into account that both onions have a relatively high amount of phenolic compounds, we wanted to further investigate their potential in protecting DNA from ROS. In that sense, the pUC19 plasmid that was exposed to Fenton's reagent served as a biological probe.

Hydroxyl radicals generated by the Fenton reaction cause the oxidatively induced DNA strand breaks to yield their open circular or relaxed form [1]. Figure 2 shows the DNA-protecting effects of $A$. cepa and A. × cornutum, where it can be seen that lower extract concentrations correlate to poor DNA protection and an increase in open circular and linear forms of DNA. On the contrary, higher concentrations show significant free radical scavenging activity and the ability to maintain a supercoiled form of DNA. Our results clearly indicate that the preservation of an intact circular plasmid is concentration-dependent $(5-100 \mu \mathrm{g} / \mathrm{mL})$.

Since both extracts have a relatively high amount of phenolic compounds (quercetin and its derivatives) which act as antioxidants, we presume that they are responsible for promoting good scavenging activity. Several other previous studies have, in turn, also reported that high phenolic content prevents DNA damage caused by hydroxyl radicals $[1,30]$.

The antioxidant activity of phenolic compounds is associated with the total number and position of the hydroxyl functional groups which are able to reduce highly oxidizing free radicals such as superoxides, peroxyls, aloxyls, and hydroxyls [31]. Other than ROS reduction by hydrogen donation, 
antioxidant action can include the suppression of ROS formation by chelating metal ions, scavenging ROS and inhibiting oxidases [6]. Since phenolic compounds act as antioxidants, it is justified to conclude that a higher phenolic content leads to a stronger antioxidant capacity. This conclusion agrees with our findings which also showed that TPC values are in correlation with DPPH scavenging and ORAC values for both onions.

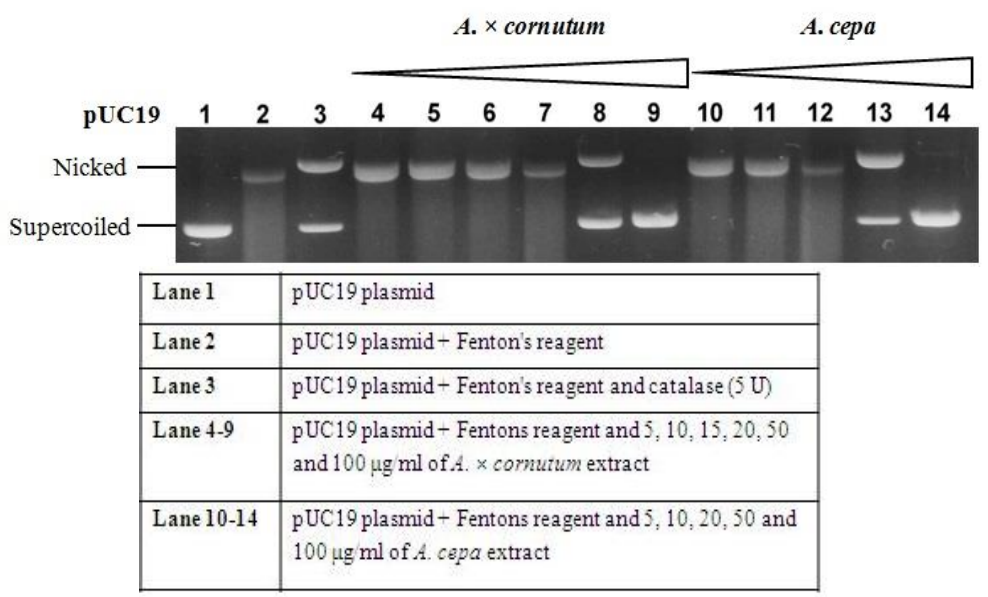

Figure 2. Protective effects of both onion extracts on supercoiled pUC19 DNA.

\subsection{Comet Assay}

The comet assay was performed to determine the possible protective effects of both onions on DNA damage in human leukocytes (white blood cells; WBCs). Incubation of leukocytes with the DNA damage-inducing reagent $\left(\mathrm{H}_{2} \mathrm{O}_{2}, 200 \mu \mathrm{M}\right)$ resulted in a significant increase of DNA damage compared to the untreated control ( $\left.{ }^{* * *} p<0.001\right)$ (Figure 3).

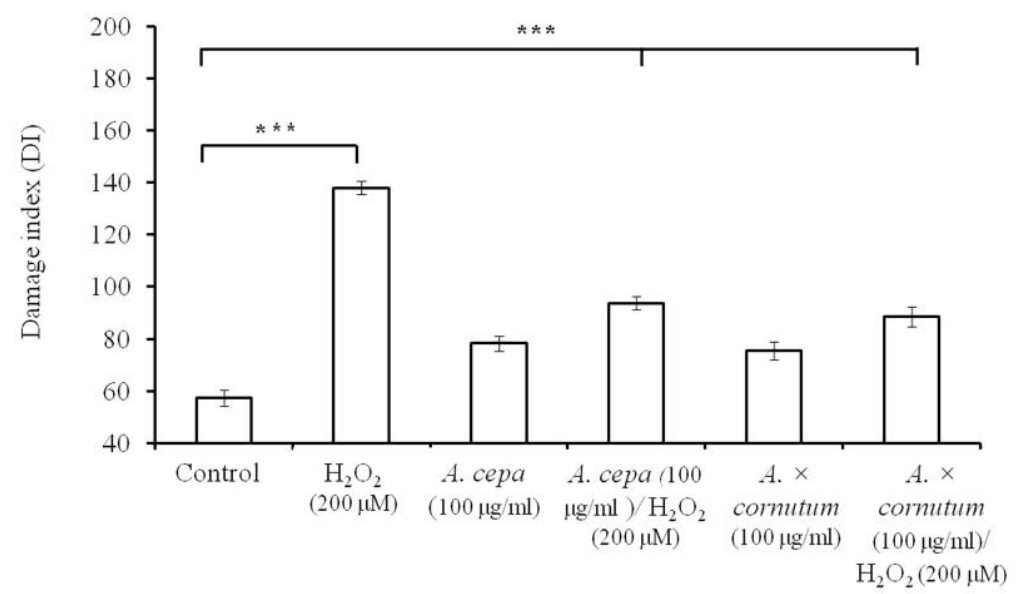

Figure 3. DNA damage index (DI) of treated human leukocytes: control, $\mathrm{H}_{2} \mathrm{O}_{2}(200 \mu \mathrm{M})$, A. cepa $(100 \mu \mathrm{g} / \mathrm{mL})$, A. cepa with $\mathrm{H}_{2} \mathrm{O}_{2}$, A. $\times$ cornutum $(100 \mu \mathrm{g} / \mathrm{mL})$, and A. $\times$ cornutum with $\mathrm{H}_{2} \mathrm{O}_{2}$; *** $p<0.001$.

Cells treated with $100 \mu \mathrm{g} / \mathrm{mL}$ A. $\times$ cornutum or A. cepa extracts showed only a moderate level of DNA damage, indicating that the presence of phytochemicals in onions can also provoke oxidative DNA damage. This is considered to be a structural property of phenolic compounds which can act as both antioxidants and prooxidants at the same time. In the presence of oxygen, some transition ionic metals, such as $\mathrm{Cu}^{2+}$ and $\mathrm{Fe}^{2+}$ or $\mathrm{Fe}^{3+}$, can cause the oxidation of flavonoids, leading to the formation of ROS, which can, in turn, damage DNA [32]. When leukocytes were simultaneously incubated 
with onion extracts and $\mathrm{H}_{2} \mathrm{O}_{2}$, a significant decrease in DNA damage was observed $(p<0.0001$ for A. $\times$ cornutum and A. cepa).

Hydrogen peroxide generates hydroxyl radicals $\left(\mathrm{OH}^{\bullet}\right)$ that cause DNA strand breaks and fragmentations. Thanks to the high levels of phenolic compounds, especially quercetin and its derivatives, $A . \times$ cornutum and $A$. cepa are able to catch and inactivate those radicals before they can induce any DNA damage (Figure 3). Quercetin and its glycosides may function as a donor and contribute a hydrogen atom from their phenolic hydroxyl group in the B-ring in order to remove hydroxyl radicals generated from hydrogen peroxide. Similar protective effects of quercetin on hydrogen peroxide-induced DNA damage were reported before [33-35]. Our results demonstrate that both extracts are able to prevent DNA damage caused by the oxidative DNA-damaging agents, such as $\mathrm{H}_{2} \mathrm{O}_{2}$ in human leukocytes.

\subsection{Cell Proliferation Assay}

To evaluate whether $A . \times$ cornutum and A. cepa methanolic extracts $(c=100 \mu \mathrm{g} / \mathrm{mL})$ have a cytotoxic effect on breast and glioblastoma cancer cell lines, cells were treated with onion extracts for $4,24,48$, and $72 \mathrm{~h}$, and the amount of metabolically active cells was measured by MTT (3-(4,5-dimethylthiazol-2-yl)-2,5-diphenyl tetrazolium bromide) assay.

As shown in Figure 4 , both extracts significantly reduced $\left({ }^{* * *} p<0.001\right)$ the number of viable cells, albeit $A . \times$ cornutum showed a slightly stronger inhibitory effect on all cancer cell lines. The most striking observation was the low viability of glioblastoma which, among other tested cancer cells, showed the highest susceptibility in the presence of both onion extracts. Our results indicate that both plants, $A$. $\times$ cornutum and A. cepa, are effective inhibitors of tumor cell proliferation, which correlates with the study of Boivin et al. [26], who have also shown a strong antiproliferative effect of Allium vegetables on different cancer cell lines.

A)

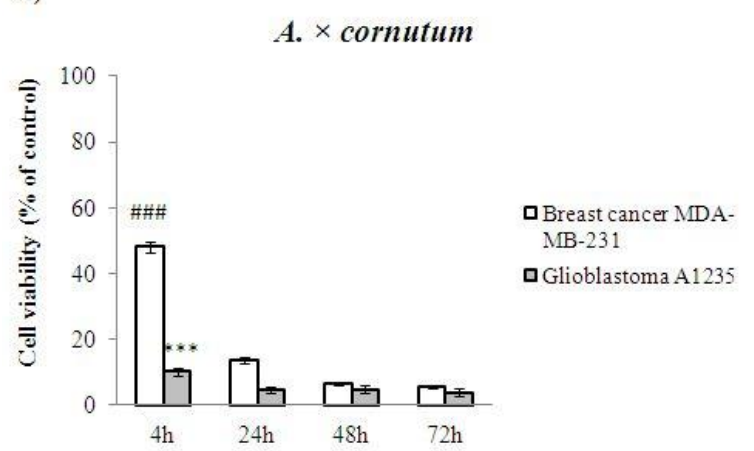

B)

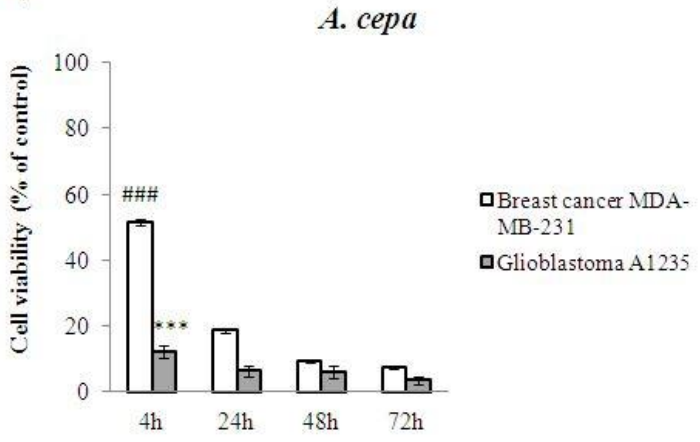

Figure 4. Cytotoxic effect of $A . \times$ cornutum and $A$. cepa methanolic extracts at concentration of $100 \mu \mathrm{g} / \mathrm{mL}$ on two human cancer cell lines: breast and glioblastoma cancer cells. The antiproliferative effect of $A . \times$ cornutum (A) and A. cepa (B) after 4, 24, 48 and $72 \mathrm{~h}$ of exposure. The percentage of metabolically active cells is expressed in comparison to the untreated control. The results are presented as a mean value $\pm \mathrm{SD}$ of the three independent experiments. The statistically significant difference of glioblastoma cell line is represented as ${ }^{* *} p<0.001$ for $A . \times$ cornutum and $A$. cepa, and the statistically significant difference of breast cancer cell line is represented as \#\#\# $p<0.001$ for $A . \times$ cornutum and A. сера.

It is worth noting that the Allium extracts used in their study also displayed strong inhibitory effects against glioblastoma cancer cells. Most importantly, the authors showed that onion extract had no impact on normal fibroblast growth, suggesting that their selective antiproliferative activity was exclusively against tumor cells. Similar results were obtained by Yang et al. [36] as they confirmed the antiproliferative effect on human epithelial colorectal adenocarcinoma cells (Caco-2) and liver hepatocellular carcinoma cells (HepG2). The authors also observed that a different range 
of antiproliferative activities depended on the onion cultivar and the type of cancer cells used in the experimental process. Therefore, the authors hypothesized that the reason for these differences could be attributed to the different types and concentrations of bioactive phytochemicals which can target different molecules or different signaling pathways in distinct cancer cell lines. Millet et al. [37] tested the antiproliferative activity of onion extracts in different solvents: fermented aqueous extract (FAE), aqueous extract (AE), and methanolic extract (ME). Only the FAE extract showed significant toxicity to HepG2 cancer cell growth, while the other two showed no impact on cell proliferation. It should also be emphasized that the inhibition of cancer cell proliferation by the two tested extracts may not be exclusively due to their polyphenolic content, but may also be attributed to their other bioactive compounds, such as organosulfur compounds, typical in the majority of Allium species. These findings are in agreement with all known anticancer properties of Allium species noticed in many other epidemiological studies [9].

\section{Materials and Methods}

\subsection{Chemical Reagents}

Low melting point (LMP), normal melting point (NMP) agarose, hydrogen peroxide $\left(\mathrm{H}_{2} \mathrm{O}_{2}\right)$, ethyl acetate, ethanol, methanol, ferric chloride $\left(\mathrm{FeCl}_{3}\right)$, caffeic acid, phosphate-buffered saline ( $\mathrm{pH}$ 7.4), dimethyl slulfoxide (DMSO), ascorbic acid, hydrochloric acid ( $\mathrm{HCl}, 37 \%)$, sodium chloride $(\mathrm{NaCl})$, sodium hydroxide $(\mathrm{NaOH})$, sodium lauryl sarcosine, disodium salt ethylene-diamin-tetra-acetic acid ( $\mathrm{Na}_{2}$ EDTA), Trizma base, Triton X-100, Folin-Ciocalteu reagent, 2,2-diphenyl-picrylhydrazyl (DPPH), 6-hydrohy-2,5,7,8-tetramethyl-2-carboxylic acid (Trolox), fluoroshield with 4',6-diamino-2-phenylindole (DAPI), quercetin $4^{\prime}$-monoglucoside, quercetin, isorhamnetin and myricetin were obtained from Sigma-Aldrich (St. Louis, MO, USA). pUC19 plasmid DNA was purchased from Invitrogen Life Technologies (Carlsbad, CA, USA). Quercetin 3,4'-diglucoside was obtained from Polyphenols AS (Sandnes, Norway), and malvidin-3-O-glucoside chloride was obtained from Extrasynthese (Genay, France). All chemicals and reagents were AR or HPLC grade.

\subsection{Plant Material}

Allium $\times$ cornutum was obtained from local gardens along the Croatian coast and islands, while the Allium cepa plants were purchased at a local market.

\subsection{Preparation of Onion Extracts}

The phenolic compounds were extracted from homogenized dry plant material $(10 \mathrm{~g})$ using $70 \%$ methanol water $(v / v ; 100 \mathrm{~mL})$. After $30 \mathrm{~min}$ of extraction with magnetic stirring at room temperature (ca. $20^{\circ} \mathrm{C}$ ), the extract was centrifuged at $3000 \mathrm{rpm}$ for $15 \mathrm{~min}$. All three supernatants were pooled and dried under vacuum using a rotary evaporator (ca. $50^{\circ} \mathrm{C}$ ). After evaporating solvent at rotavap, samples were dried in a vacuum oven until they reached constant weight. The dry residues were dissolved with $10 \%$ DMSO. For HPLC analysis, the solution was filtered through a $0.45 \mu$ m nylon filter disc prior to analysis.

\subsection{Analysis of the Phytochemicals}

\subsubsection{HPLC Analysis of Flavonols}

High-performance liquid chromatography (HPLC) measurement of flavonols were carried out using the Perkin Elmer HPLC system (Waltham, Massachusetts, USA) consisting of a binary pump Series 200, an autosampler, Peltier column oven Series 200, UV-VIS detector Series 200, and UltraAqueous C18 column $(250 \times 4.6 \mathrm{~mm}$, Resek, Bellefonte, PA, USA). TotalChrom Workstation software (version 6.2.1, Perkin Elmer), was used to process the chromatographic data. After filtration 
through a $0.45 \mu \mathrm{m}$ syringe filter, the extract was injected directly through a $20 \mu \mathrm{L}$ fixed loop into a guard of the $\mathrm{C} 18$ column. Each sample was injected three times in order to check its reproducibility. A gradient consisting of solvent $\mathrm{A}\left(0.2 \% \mathrm{H}_{3} \mathrm{PO}_{4}\right)$ and solvent $\mathrm{B}(\mathrm{MeOH} /$ acetonitrile, $1: 1 \mathrm{v} / \mathrm{v})$ was applied at a flow rate of $0.8 \mathrm{~mL} / \mathrm{min}$ as follows: $0-0.5 \mathrm{~min} 96 \% \mathrm{~A}$ and $4 \% \mathrm{~B} ; 0.5-40 \mathrm{~min} 50 \% \mathrm{~A}$ and $50 \%$ B; $40-45 \min 40 \% \mathrm{~A}$ and $60 \% \mathrm{~B} ; 45-60 \mathrm{~min} 0 \% \mathrm{~A}$ and $100 \% \mathrm{~B} ; 60-68 \mathrm{~min} 0 \% \mathrm{~A}$ and $100 \% \mathrm{~B} ; 68-70 \mathrm{~min}$ $96 \% \mathrm{~A}$ and $4 \% \mathrm{~B} ; 70-80 \mathrm{~min} 96 \% \mathrm{~A}$ and $4 \%$ B. Detection of the elution peaks was at $\lambda=360 \mathrm{~nm}$. Flavonoid compounds were identified on the basis of their retention times and quantified using external standard calibration curves. Standards for identification purposes were: quercetin, quercetin $4^{\prime}$-monoglucoside, and quercetin 3,4'-diglucoside prepared in methanol. The resultant concentrations are expressed as $\mathrm{mg} / 100 \mathrm{~g}$ of dry weight.

\subsubsection{HPLC Analysis of Anthocyanins}

HPLC analysis of anthocyanins was performed using a Varian HPLC system (Varian, Inc., Harbour City, CA, USA), consisting of a Star 9010 pump, a Rheodyne 7125 syringe loading sample injector, a 500-LC module for a column oven, a ProStar 330 photodiode array detector, and a Star Chromatography workstation, version 5 . The separation was carried out using a Kinetex C18 core-shell column $(150 \times 4.6 \mathrm{~mm})$, filled with $5 \mu \mathrm{m}$ particles, and furnished with the SecurityGuard ULTRA Cartridge UHPLC C18 for $4.6 \mathrm{~mm}$ ID column (Phenomenex, Torrance, CA, USA), both termostated at $35{ }^{\circ} \mathrm{C}$. Two eluents were used: $\mathrm{A}$ was $0.3 \% \mathrm{HClO}_{4}$ and $\mathrm{B}$ was $\mathrm{MeOH}$. The linear gradient was as follows: from $28 \%$ B to $51 \%$ B in $42 \mathrm{~min}$, than to $69 \%$ in $3 \mathrm{~min}$ and to $80 \% \mathrm{~B}$ in $1 \mathrm{~min} 80 \%$ B for $3 \mathrm{~min}$. The time of equilibration for the column to the initial gradient was $6 \mathrm{~min}$, and the injection volume was $10 \mu \mathrm{L}$. The flow rate was $0.6 \mathrm{~mL} / \mathrm{min}$ [38]. Samples and standards were filtered before analysis through a $0.45 \mu \mathrm{m}$ pore size membrane syringe filters. Anthocyanins were identified according to the retention times of each peak at $520 \mathrm{~nm}$. Quantifications were performed using a standard curve of malvidin-3-O-glucoside chloride. The resultant concentrations are expressed as $\mathrm{mg} / 100 \mathrm{~g}$ of dry weight.

\subsubsection{Determination of Total Phenolic Content}

The total phenolic content (TPC) of $A . \times$ cornutum and A. cepa methanolic extracts was determined using Folin-Ciocalteu method described by Singleton and Rossi [39]. Briefly, the determination of TPC in tested samples was carried out using $10 \mathrm{~mL}$ of previously-diluted Folin-Ciocalteu reagent $(1: 20 \mathrm{v} / \mathrm{v})$ and $50 \mu \mathrm{L}$ of onion extract. After $3 \mathrm{~min}$ of incubation, $1 \mathrm{~mL}$ of saturated sodium carbonate was added after which the reaction mixture was incubated for another $60 \mathrm{~min}$ in the dark and the absorbance was measured at $725 \mathrm{~nm}$ using the Perkin Elmer UV-VIS Lambda Bio 40 spectrophotometer (Waltham, MA, USA). Caffeic acid served as the standard and results were expressed as $\mathrm{mg}$ of CA equivalents per $\mathrm{g}$ of dry weight. All measurements were carried out in triplicate and the results are expressed as mean values \pm SD.

\subsection{Antioxidant Activity}

\subsubsection{Measurement of the DPPH Radical Scavenging Activity}

Antioxidant capacity of extracts was evaluated using the DPPH method previously described by Kulišić, Dragović-Uzelac, and Miloš [40]. This method is based on the reduction of alcoholic DPPH solution in the presence of a hydrogen-donating antioxidant. An aliquot $(50 \mu \mathrm{L})$ of the onion extract was mixed with a methanolic solution of DPPH $(1 \mathrm{~mL}, 0.1 \mathrm{mM})$ and the initial absorbance at $517 \mathrm{~nm}$ was measured immediately using EtOH as a blank. After $60 \mathrm{~min}$ of incubation, the absorbance was measured again and the percentage of DPPH inhibition was calculated according to the formula by Yen and Duh [41]:

$$
\% \text { inhibition }=\left(\left(\mathrm{A}_{\mathrm{C}}(0)-\mathrm{A}_{\mathrm{A}}(t)\right) / \mathrm{A}_{\mathrm{C}}(0) \times 100,\right.
$$


where $\mathrm{A}_{\mathrm{C}}(0)$ is the absorbance of the control at $t=0 \mathrm{~min}$, and $\mathrm{A}_{\mathrm{A}}(t)$ is the absorbance of the antioxidant at $t=1 \mathrm{~h}$. All measurements were performed in triplicate.

\subsubsection{Oxygen Radical Absorbance Capacity Assay}

The assay was performed in Perkin-Elmer LS55 spectrofluorimeter, using 96-well white polystyrene microtiter plates (Porvair Sciences, Leatherhead, UK). Each reaction contained $190 \mu \mathrm{L}$ of fluorescein $(160 \mu \mathrm{M}), 60 \mu \mathrm{L}$ 2,2'-Azobis(2-methyl-propionamidine) dihydrochloride (AAPH) (150 mM), and $30 \mu \mathrm{L}$ of plant extracts or reference standard Trolox $(6.25-50 \mu \mathrm{M})$. All experimental solutions and samples were prepared in a phosphate buffer $(0.075 \mathrm{mM}, \mathrm{pH} 7.0)$. The measurements were performed in triplicate at $37^{\circ} \mathrm{C}$ using the excitation wavelength of $485 \mathrm{~nm}$, and the fluorescence decay was monitored at $530 \mathrm{~nm}$ during the period of $60 \mathrm{~min}$. The obtained fluorescence decay curves were analyzed by FL WinLab software (version 4.00.03, Perkin-Elmer) and the resultant area under the curve (AUC) of each standard or sample was acquired after the blank AUC subtraction (Figure S1). The standard curve was generated by plotting the AUC of standards with corresponding nmol of trolox. The ORAC values of onion extracts were expressed as $\mu$ mol of trolox equivalents (TE) per $\mathrm{mL}$ of tested sample. The results were obtained from three independent experiments.

\subsection{Evaluation of Biological Activity}

\subsubsection{Blood Sampling and Treatment of Human Leukocytes}

Blood samples were obtained from a healthy female donor (age 28, non-smoker, the first author of this paper, and the protocol was approved by the Ethics Committee of School of Medicine, University of Zagreb, code: 380-59-10106-14-55/118, 2014). Venous blood was collected into heparinized vacutainer tubes (Becton Dickeson, Plymouth, UK) under sterile conditions. Leukocytes were isolated by gradient centrifugation with a Histopaque-1077 (Sigma) at $400 \times g$ for $30 \mathrm{~min}$ and washed twice with phosphate-buffered saline (PBS). Cell viability was determined with trypan blue exclusion assay. Leukocytes $\left(2 \times 10^{6}\right.$ cells $\left./ \mathrm{mL}\right)$ were then incubated in RPMI-1640 medium (Gibco, Invitrogen, Carlsbad, CA, USA) and supplemented with $A . \times$ cornutum and $A$. cepa methanolic extract $(100 \mu \mathrm{g} / \mathrm{mL})$ for $30 \mathrm{~min}$ at $37{ }^{\circ} \mathrm{C}$ in a humidified atmosphere with $5 \% \mathrm{CO}_{2}$. Cells growing in a medium supplemented with $1 \%$ DMSO were used as the negative control and those incubated with $200 \mu \mathrm{M}$ of $\mathrm{H}_{2} \mathrm{O}_{2}$ (for $5 \mathrm{~min}$, $4{ }^{\circ} \mathrm{C}$ ) served as the positive control. After incubation, cells were centrifuged at $300 \times g$ for 5 min at $4{ }^{\circ} \mathrm{C}$ and washed twice with PBS. Supernatant was discarded and the pellet was placed on ice and resuspended in LMP agarose. All treatments were performed in duplicate.

\subsubsection{Comet Assay (Single-Cell Gel Electrophoresis)}

The alkaline comet assay was carried out according to the procedure of Singh et al. [42]. Conventional microscope slides were precoated by dipping them in a solution of $1 \%$ normal melting point agarose and left to dry overnight. After treatment, the cells were centrifuged $\left(300 \times g, 5 \mathrm{~min}, 4^{\circ} \mathrm{C}\right)$ and the supernatant was removed. The pellet was resuspended in the RPMI medium and the cells were counted. Approximately $1 \times 10^{6}$ cells $/ \mathrm{mL}$ were mixed with $100 \mu \mathrm{L} 0.5 \%$ LMP agarose and placed on a precoated slide. After solidification of the agarose, the slides were immersed in fresh ice-cold lysis solution (2.5 M NaCl, $0.1 \mathrm{Na}_{2}$ EDTA, $10 \mathrm{mM}$ Tris-Cl, 10\% DMSO, $1 \%$ sodium lauryl sarcosine, $1 \%$ Triton $\mathrm{X}-100, \mathrm{pH} 10$ ) overnight at $4{ }^{\circ} \mathrm{C}$. Alkaline denaturation was performed in an electrophoresis buffer solution ( $1 \mathrm{mM} \mathrm{Na} \mathrm{a}_{2}$ EDTA and $\left.300 \mathrm{mM} \mathrm{NaOH}, \mathrm{pH} \geq 13\right)$ for $20 \mathrm{~min}$. Electrophoresis was carried out in a chilled electrophoresis buffer for $20 \mathrm{~min}\left(25 \mathrm{~V}, 300 \mathrm{~mA}, 4^{\circ} \mathrm{C}\right)$. The slides were then washed three times for $5 \mathrm{~min}$ in $0.4 \mathrm{M}$ Tris-Cl, $\mathrm{pH} 7$, treated with ethanol for another $5 \mathrm{~min}$, and dried. For comet analysis, the slides were stained with DAPI $(5 \mu \mathrm{g} / \mathrm{mL})$. A total of 100 comets (50 cells from each of the two replicated slides) were scored visually in five classes according to tail size and intensity (from undamaged 0; to maximally damaged 4) as depicted in Figure 5. DNA damage index was determined according to the equation: 


$$
\mathrm{DI}=1 n 1+2 n 2+3 n 3+4 n 4
$$

where DI is the damage index in arbitrary units (AU), $n 1-n 4$ are the number of comets with damage levels 1, 2, 3 and 4. DI values can indicate various situations, from all undamaged cells (class 0; 0 AU) to highly damaged cells (class $4 ; 400 \mathrm{AU}$ ).
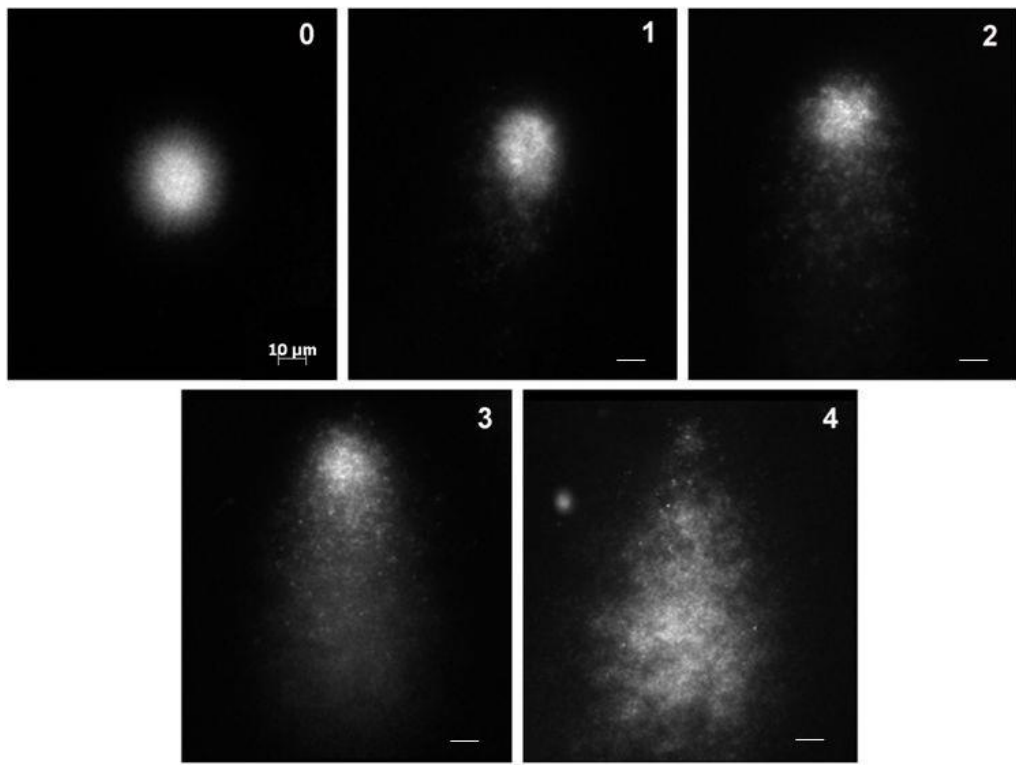

Figure 5. Grading of the DNA damage in human leukocytes: (0) no damage; (1) low level of DNA damage; (2) medium level of DNA damage; (3) high level of DNA damage; and (4) maximum level of DNA damage. Bar in the first picture $(0)=10 \mu \mathrm{m}$, and is also valid for all micrographs.

\subsubsection{DNA Nicking Assay}

DNA nicking assay was performed using supercoiled pUC19 plasmid DNA by the method of Prakash et al. A reaction mixture containing different concentrations of plant extracts $(10-100 \mu \mathrm{g} / \mathrm{mL})$ and pUC19 plasmid DNA $(0.5 \mu \mathrm{g})$ was incubated for $10 \mathrm{~min}$ at room temperature, followed by the addition of Fenton's reagent $\left(30 \mathrm{mM} \mathrm{H}_{2} \mathrm{O}_{2}, 50 \mu \mathrm{M}\right.$ ascorbic acid, and $80 \mu \mathrm{M}$ of $\left.\mathrm{FeCl}_{3}\right)$. The reaction mixture was then incubated for $30 \mathrm{~min}$ at $37^{\circ} \mathrm{C}$ and the DNA was analyzed on a $1 \%$ agarose gel.

\subsubsection{Cell Culture}

Cells were purchased from ATCC (LGC Standards, Bury, UK). Cancer cell lines (breast cancer cell line MDA-MB-231 and human glioblastoma cell line-A1235) were cultured in a humidified atmosphere with $5 \% \mathrm{CO}_{2}$ at $37^{\circ} \mathrm{C}$, in a Dulbecco's modified Eagle's medium (DMEM Euroclone, Milano, Italy) containing $4.5 \mathrm{~g} / \mathrm{L}$ glucose, $10 \%$ fetal bovine serum (FBS), and $1 \%$ antibiotics (penicillin and streptomycin, EuroClone).

\subsubsection{Cell Proliferation Assay}

Cells were resuspended in a diluted solution of trypan blue and counted by a binocular inverted microscope, MOTIC AE30 (Motic, Barcelona, Spain), using Neubauer chambers. The cell number was calculated according to the formula: number of counted cells $\times 10^{4} / \mathrm{mL}$. The cells were then plated in 96-well plates at a density of 11,000 cells/well and incubated overnight. The cells were treated with $A$. $\times$ cornutum and A. cepa methanolic extract at a concentration of $100 \mu \mathrm{g} / \mathrm{mL}$ in a complete medium (in triplicate) for 4, 24, 48 and $72 \mathrm{~h}$. Then, the MTT assay was performed in such a manner that after the treatment with onion extracts, the cells were incubated with $0.5 \mathrm{~g} \mathrm{MTT} / \mathrm{L}$ at $37^{\circ} \mathrm{C}$ for $2 \mathrm{~h}$. After that, the medium was removed and dimethylsulphoxide (10\% DMSO) was added and incubated 
for another $10 \mathrm{~min}$ at $37^{\circ} \mathrm{C}$ while shaking. The degree of formazan formation, an indicator of living and metabolically active cells, was measured photometrically at $570 \mathrm{~nm}$. The data was calculated in relation to the untreated control $(100 \%)$ from three independent measurements.

\subsection{Statistical Analysis}

Results are expressed as mean values with depicted standard deviation. Microsoft Excel Student $t$-test was used to analyze data and to discriminate statistically significant results.

\section{Conclusions}

This was the first known thoroughly comprehensive study of the phytochemical composition and biological activity of $A . \times$ cornutum. The HPLC analysis revealed two major quercetin conjugates (quercetin 3,4'-diglucoside and quercetin $4^{\prime}$-monoglucoside) as the most abundant flavonols in A. $\times$ cornutum and A. cepa extracts. Additionally, we successfully identified three anthocyanins in both onions, while the fourth anthocyanin, delphinidin glucoside, was observed only in A. $\times$ cornutum. Overall, $A$. $\times$ cornutum showed slightly higher concentrations of all identified phenolic compounds, which may be the cause of the higher bioactivity profile accounted for in this onion.

Our results clearly indicate that both onions have strong protective effects on the DNA molecule, as was proven with several different in vitro experiments. Both onions have also shown strong antiproliferative activity on human cancer cell lines; however, the susceptibility of glioblastoma cells against both onion extracts was higher than that of a breast cancer cell line. The antiproliferative activity of the tested methanol extracts could be mediated by the induction of apoptosis, alterations of the cell cycle, or some other mechanism, while further research is needed to clarify the exact mechanism(s) of their antiproliferative activity in vitro. Therefore, it can be concluded that $A . \times$ cornutum and A. cepa methanolic extracts have a comparable composition and concentrations of phenolic compounds, as well as antioxidant, antigenotoxic and antiproliferative effects. This research demonstrated that A. $\times$ cornutum and common onions should be considered as important sources of natural antioxidants that have a beneficial protective effect on human health.

Supplementary Materials: Supplementary materials are available online. Figure S1. Fluorescence decay curve of methanolic extracts of A. cepa (- - ), A. × cornutum (- - ) and blank (-); Figure S2. High-performance liquid chromatography (HPLC) chromatogram of $A$. $\times$ cornutum anthocyanins at $520 \mathrm{~nm}$. Depicted are peaks: peonidine 3'-glucoside, petunidin 3'-glucoside, delphidin 3'-glucoside and malvidin 3'-glucoside; Figure S3. High-performance liquid chromatography chromatogram of $A$. cepa anthocyanins at $520 \mathrm{~nm}$. Depicted are peaks: peonidine 3'-glucoside, petunidin 3'-glucoside and malvidin 3'-glucoside.

Acknowledgments: This work was supported by the Croatian Ministry of Science, Education and Sports as part of multiannual financing intended for institutions.

Author Contributions: J.P. and Ž.F. conceived and designed the experiments; Ž.F., M.̌̌., B.S., I.L., I.B.-L., T.B., and V.Č.-Č. performed the experiments; Ž.F. and M.Š. analyzed the data; J.P., Ž.F. and M.Š. wrote the paper.

Conflicts of Interest: The authors declare no conflict of interest. The founding sponsors had no role in the collection, analyses, or interpretation of data, and in the writing of the manuscript.

\section{References}

1. Prakash, D.; Singh, B.N.; Upadhyay, G. Antioxiodant and free radical scavenging activities of phenols from onion (Allium cepa). Food Chem. 2007, 102, 1389-1393. [CrossRef]

2. Razavi-Azarkhavi, K.; Behravan, J.; Mosaffa, F.; Sehatbakhsh, S.; Shirani, K.; Karimi, G. Protective effects of aqueous and ethanol extracts of rosemary on $\mathrm{H}_{2} \mathrm{O}_{2}$-induced oxidative DNA damage in human lymphocytes by comet assay. J. Complement. Integr. Med. 2014, 11, 27-33. [CrossRef] [PubMed]

3. Özyürek, M.; Bener, M.; Güçlü, K.; Apak, R. Antioxidant/antiradical properties of microwave-assisted extracts of three wild edible mushrooms. Food Chem. 2014, 157, 323-331. [CrossRef] [PubMed]

4. Puizina, J.; Javornik, B.; Bohanec, B.; Schweizer, D.; Maluszynska, J.; Papeš, D.; Schweizer, D. Random amplified polymorphic DNA analysis, genome size, and genomic in situ hybridization of triploid viviparous onions. Genome 1999, 42, 1208-1216. [CrossRef] [PubMed] 
5. Corzo-Martínez, M.; Corzo, N.; Villamiel, M. Biological properties of onions and garlic. Trends Food Sci. Technol. 2007, 18, 609-625. [CrossRef]

6. Lanzotti, V. The analysis of onion and garlic. J. Chromatogr. A 2006, 1112, 3-22. [CrossRef] [PubMed]

7. Gurushizde, M.; Mashayekhi, S.; Blattner, F.R.; Friesen, N.; Fritsch, R.M. Phylogenetic relationship of wild and cultivated species of Allium section Cepa inferred by nuclear rDNA ITS sequence analysis. Plant Syst. Evol. 2007, 269, 259-269. [CrossRef]

8. Kendler, B.S. Garlic (Allium sativum) and onion (Allium cepa): A review of their relationship to cardiovascular disease. Prev. Med. 1987, 16, 670-685. [CrossRef]

9. Nicastro, H.L.; Ross, S.A.; Milner, J.A. Garlic and onions: Their cancer prevention properties. Cancer Prev. Res. 2015, 8, 181-189. [CrossRef] [PubMed]

10. Yang, E.-J.; Kim, G.-S.; Kim, J.A.; Song, K.-S. Protective effects of onion-derived quercetin on glutamate-mediated hippocampal neuronal cell death. Pharmacogn. Mag. 2013, 9, 302-308. [PubMed]

11. Goldman, I.L.; Kopelberg, M.; Debaene, J.E.; Schwartz, B.S. Antiplatelet activity in onion (Allium cepa) is sulfur dependent. Throm. Haemost. 1996, 76, 450-452.

12. Bonaccorsi, P.; Caristi, C.; Gargiulli, C.; Leuzzi, U. Flavonol glucosides in Allium species: A comparative study by means of HPLC-DAD-ESI-MS-MS. Food Chem. 2008, 107, 1668-1673. [CrossRef]

13. Griffiths, G.; Trueman, L.; Crowther, T.; Thomas, B.; Smith, B. Onions-A global benefit to health. Phytother. Res. 2002, 16, 603-615. [CrossRef] [PubMed]

14. Gennaro, L.; Leonardi, C.; Esposito, F.; Salucci, M.; Maiani, G.; Quaglia, G.; Fogliano, V. Flavonoid and carbohydrate contents in Tropea red onions: Effects of homelike peeling and storage. J. Agric. Food Chem. 2002, 50, 1904-1910. [CrossRef] [PubMed]

15. Fredotović, Ž.; Šamanić, I.; Schneeweiss-Weiss, H.; Kamenjarin, J.; Jang, T.-S.; Puizina, J. Triparental origin of triploid onion, Allium $\times$ cornutum (Clementi ex Visiani, 1842), as evidenced by molecular, phylogenetic and cytogenetic analysis. BMC Plant Biol. 2014, 14, 14-24. [CrossRef] [PubMed]

16. Caridi, D.; Trenerry, V.C.; Rochfort, S.; Duong, S.; Laugher, D.; Jones, R. Profiling and quantifying quercetin glucosides in onion (Allium cepa L.) varieties using capillary zone electrophoresis and high performance liquid chromatography. Food Chem. 2007, 105, 691-699. [CrossRef]

17. Lombard, K.A.; Geoffriau, E.; Peffley, E. Flavonoid quantification in onion by spectrophotometric and high performance liquid chromatography analysis. Hortic. Sci. 2002, 37, 682-685.

18. Pérez-Gregorio, R.M.; García-Falcón, M.S.; Sinal-Gándara, J.; Rodrigues, A.S.; Almeida, D.P.F. Identification and quantification of flavonoids in traditional cultivars of red and white onions at harvest. J. Food Comp. Anal. 2010, 23, 592-598. [CrossRef]

19. Price, K.R.; Rhodes, M.J.C. Analysis of the major flavonol glycosidespresent in four varieties of onion (Allium cepa) and changes in composition resulting from autolysis. J. Sci. Food Agric. 1997, 74, 331-335. [CrossRef]

20. Rhodes, M.; Price, K. Analytic problems in the study of flavonoid compounds in onion. Food Chem. 1996, 57, 113-117. [CrossRef]

21. Santas, J.; Carbo, R.; Gordon, M.H.; Almajano, M.P. Comparison of the antioxidant activity of two Spanish onion varieties. Food Chem. 2008, 107, 1210-1216. [CrossRef]

22. Nile, S.H.; Park, S. Total phenolics, antioxidant and xanthine oxidase inhibitory activity of three colored onions (Allium cepa L.). Front. Life Sci. 2014, 7, 224-228. [CrossRef]

23. Sharma, K.; Assefa, A.D.; Kim, S.; Young Ko, E.; Lee, E.T.; Park, S.W. Evaluation of total phenolics, flavonoids and antioxidant activity of 18 Korean onion cultivars: A comparative study. J. Sci. Food Agric. 2014, 94, 1521-1529. [CrossRef] [PubMed]

24. Zill, H.; Fabiano-Tixier, A.-S.; Elmaataoui, M.; Dangles, O.; Chemat, F. A remarkable influence of microwave extraction: Enhancement of antioxidant activity of extracted onion varieties. Food Chem. 2011, 127, 1472-1480. [CrossRef]

25. Benekeblia, N. Free-radical scavenging capacity and antioxidant properties of some selected onions (Allium cepa L.) and garlic (Allium sativum L.) extracts. Braz. Arch. Biol. Technol. 2007, 48, 753-759. [CrossRef]

26. Boivin, D.; Lamy, S.; Lord-Dufour, S.; Jackson, J.; Beaulieu, E.; Côté, M.; Moghrabi, A.; Barrete, S.; Gingras, D.; Béliveau, R. Antiproliferative and antioxidant activities of common vegetables: A comparative study. Food Chem. 2009, 112, 374-380. [CrossRef] 
27. Miller, H.E.; Rogelhof, F.; Marguart, L.; Prakash, A.; Kanter, M. Antioxidant content of whole grain breakfast cereals, fruits and vegetables. J. Am. Coll. Nutr. 2008, 19, 1-8. [CrossRef]

28. Nuutila, A.M.; Puupponen-Pimiä, R.; Oksman-Caldentey, K.-M. Comparison of antioxidant activities of onion and garlic extracts by inhibition of lipid peroxidation and radical scavenging activity. Food Chem. 2003, 81, 485-493. [CrossRef]

29. Yin, M.; Cheng, W. Antioxidant activity of several Allium members. J. Agric. Food Chem. 1998, 46, 4097-4101. [CrossRef]

30. Singh, B.N.; Singh, B.R.; Singh, R.L.; Prakash, D.; Singh, D.P.; Sharma, B.K.; Upadhyay, G.; Singh, H.B. Polyphenolics from various extracts / fractions of red onion (Allium cepa) peel with potent antioxidant and antimutagenic activities. Food Chem. Toxicol. 2009, 47, 1161-1167. [CrossRef] [PubMed]

31. Kumar, S.; Pandey, A.K. Chemistry and biological activities of flavonoids: An overview. Sci. World J. 2013, 2013, 162750. [CrossRef] [PubMed]

32. Sakihama, Y.; Cohen, M.F.; Grace, S.C.; Yamasaki, H. Plant phenolic antioxidant and prooxidant activities: Phenolics-induced oxidative damage mediated by metals in plants. Toxicology 2002, 177, 67-80. [CrossRef]

33. Duthie, S.J.; Collins, A.R.; Duthie, G.G.; Dobson, V.L. Quercetin and myricetin protect against hydrogen peroxide- induced DNA damage (strand breaks and oxidized pyrimidines) in human lymphocytes. Mutat. Res. 1997, 393, 223-231. [CrossRef]

34. Noroozi, M.; Angerson, W.J.; Lean, M.E. Effects of flavonoids and vitamin C on oxidative DNA damage to human lymphocytes. Am. J. Clin. Nutr. 1998, 67, 1210-1218. [PubMed]

35. Johnson, M.K.; Loo, G. Effects of epigallocatechin gallate and quercetin on oxidative damage to cellular DNA. Mutat. Res. 2000, 459, 211-218. [CrossRef]

36. Yang, J.; Meyers, K.J.; van der Heide, J.; Liu, R.H. Varietal differences in phenolic content and antioxidant and antiproliferative activities of onions. J. Agric. Food Chem. 2004, 52, 6787-6793. [CrossRef] [PubMed]

37. Millet, A.; Lamy, E.; Jonas, D.; Stintzing, F.; Mersch-Sundermann, V.; Merfort, I. Fermentation enhances the biological activity of Allium cepa bulb extracts. J. Agric. Food Chem. 2012, 60, 2148-2156. [CrossRef] [PubMed]

38. Vanzo, A.; Terdoslavich, M.; Brandoni, A.; Torres, A.M.; Vrhovsek, U.; Passamonti, S. Uptake of grape anthocyanins into the rat kidney and the involvement of bilitranslocase. Mol. Nutr. Food Res. 2008, 52, 1106-1116. [CrossRef] [PubMed]

39. Singleton, V.L.; Rossi, J.A. Colorimetry of total phenolics with phosphomolybdic phosphotungstic acid reagents. Am. J. Enol. Vitic. 1965, 12, 99-101.

40. Kulišić, T.; Dragović-Uzelac, V.; Miloš, M. Antioxidant activity of aqueous tea infusions prepared from oregano, thyme and wild thyme. Food Technol. Biotechnol. 2006, 44, 485-492.

41. Yen, G.C.; Duh, P.D. Scavenging effect of methanolic extracts of peanut hulls on free-radical and active oxygen species. J. Agric. Food Chem. 1994, 43, 629-632. [CrossRef]

42. Singh, N.P.; McCoy, M.T.; Tice, R.R.; Schneider, E.L. A simple technique for quantification of low levels of DNA damage in individual cells. Exp. Cell Res. 1988, 175, 184-191. [CrossRef]

Sample Availability: Samples are available from the authors.

(C) 2017 by the authors. Licensee MDPI, Basel, Switzerland. This article is an open access article distributed under the terms and conditions of the Creative Commons Attribution (CC BY) license (http:/ / creativecommons.org/licenses/by/4.0/). 